\title{
STUDY ON ADAPTABILITY OF RUBBER DAM CLAMPS ON PRIMARY SECOND MOLARS IN KOREAN CHILDREN
}

\author{
Mirae Park', Yon-joo Mah¹, Byung Duk Ahn² \\ 'Division of Pediatric Dentistry, Department of Dentistry, Ewha Womans University Mokdong Hospital, Seoul, Republic of Korea \\ ${ }^{2}$ Division of Pediatric Dentistry, Department of Dentistry, Ewha Womans University School of Medicine, Seoul, Republic of Korea
}

\section{Abstract}

The purpose of this study was to investigate the mesiodistal widths at the cervical level of primary second molars in Korean children, and to compare them with commercial rubber dam clamps commonly used in pediatric dentistry.

Dental casts of 115 primary and mixed dentition children were studied. Cervical mesiodistal width (C-MD) was measured at the clinical cervical level of each primary second molar from buccal and lingual sides using a digital caliper (Absolute, Mitutoyo, Kawasaki, Japan). The data were compared with mesiodistal widths of rubber dam clamps \#203/204, \#10/11, and \#205 (Dentech, Japan).

C-MDs of primary mandibular second molars were larger than those of primary maxillary second molars, and C-MDs at buccal sides were larger than those of lingual sides. All C-MDs showed statistically significant discrepancies to corresponding widths on clamps $(p<0.05)$. However the amount of discrepancy was mild in maxillary teeth, while up to $1 \mathrm{~mm}$ of discrepancy was shown in mandibular teeth.

In conclusion, C-MDs measured in this study imply a relatively fair fit of \#10/\#11 or \#203/\#204 clamps on primary maxillary second molars, while suggesting our need for a better clamp with proper size for primary mandibular second molars.

Key words : Rubber dam clamps, Tooth cervix, Deciduous tooth

\section{Introduction}

Proper usage of rubber dam is an integral part in increasing the overall quality of dental care ${ }^{1)}$. Its role of excluding saliva, blood, and gingival fluid from the operation field is important for resin base materials, which require a dry field for optimal bonding, minimal microleakage, and longevity ${ }^{2}$. It also improves operator's visibility, reduces time of operation, protects patients from aspiration of foreign bodies, and prevents damage to surrounding tissues.
Importance of rubber dam is even increased in pediatric dentistry. Risk of soft tissue damage is increased in pediatric patients due to sudden movement of children. Rubber dam provides additional benefits as an adjunct to behavior management and can act as a tool to limit talking during treatment ${ }^{3}$. During administration of ni- $^{-}$ trous oxide sedation, rubber dam prevents leakage of nitrous oxide gas from patient's mouth, maintaining adequate level of sedation and protecting dental staffs from inhaling the gas ${ }^{4)}$.

Consistent with these advantages of rubber dam use

Corresponding author : Byung Duk Ahn, DDS, MSD

Department of Dentistry, Ewha Womans University School of Medicine, 911-1 Mok-dong, Yangcheon-gu, Seoul, 158-710, Republic of Korea

Tel: +82-2-2650-2660 / Fax: +82-2-2650-5764 / E-mail: bdspeed@eumc.ac.kr

Received December 20, 2012 / Revised May 3, 2013 / Accepted May 6, 2013 
in pediatric dentistry, a survey by Schorer-Jensma and Veerkamp ${ }^{5}$ showed that pediatric dentists use significantly more often rubber dam compared to general dentists. However, some common reasons cited for not using rubber dam were: low patient acceptability; potential painful stimulus; and time for application ${ }^{3)}$. These have a lot to do with ill-fitting rubber dam clamps. Ill-fitting rubber dam clamps can cause gingival impingement, pain, and leakage of water, which can all lead to poor cooperation in children and can act as stimuli that awaken the children during sedation. Local anesthesia is often used prior to rubber dam clamp application in pediatric patients to reduce discomfort and pain ${ }^{6}$, and products such as OraSeal ${ }^{\circledR}$ (Ultradent Products, Inc., South Jordan, UT) are used to seal leaking areas around clamps.

The fit of the rubber dam essentially depends on the choice of an appropriate clamp and its correct positioning. However, to select an appropriate clamp, clamps manufactured according to precise size and morphology of the tooth on which to be applied should be available. Many studies show significant difference in tooth size between races $^{7-9}$. This implies that commercial rubber dam clamps commonly used may fit well to teeth of one population but not to another. Moreover, while many previous studies on mesiodistal widths of teeth exist, most of them are done in purpose of orthodontic space analysis or descriptive tooth studies, measuring the greatest distance between contact points ${ }^{10)}$. Not enough information is given in regard to mesiodistal widths at the clinical cervical level of a tooth, where rubber dam clamps are actually placed.
Thus the purpose of this study was to investigate the mesiodistal widths at the cervical level of primary second molars in Korean children, and to compare them with commercial rubber dam clamps commonly used in pediatric dentistry.

\section{Materials and methods}

Dental casts of 115 primary and mixed dentition children (67 males, 48 females) attending the Department of dentistry, division of pediatric dentistry and division of orthodontics at Ewha Womans University Mokdong Hospital, Seoul, Republic of Korea, were studied, with previous approval from the Institutional Review Board (ECT 12-20B-13). Age ranged from 4 to 11-years-old. The inclusion criteria were complete eruption of the tooth to be measured, good quality dental casts, and absence of dental agenesis. Teeth with incomplete eruption, extra or abnormal cusps, morphological agenesis, and severe destructions or restorations in interproximal surfaces were excluded. From dental casts of 115 children, 91 primary maxillary right second molars, 93 primary maxillary left second molars, 97 primary mandibular right second molars, and 96 primary mandibular left second molars were included for measurements.

Mesiodistal widths were measured at the clinical cervical level from buccal and lingual sides respectively, at points considered ideal for rubber dam clamp prongs (sharp pointed ends of each jaw of the clamp) to be placed for stable adaptation. For reproducibility, the cervical mesiodistal width (C-MD) was defined in this study as distance between the following mesial and dis-
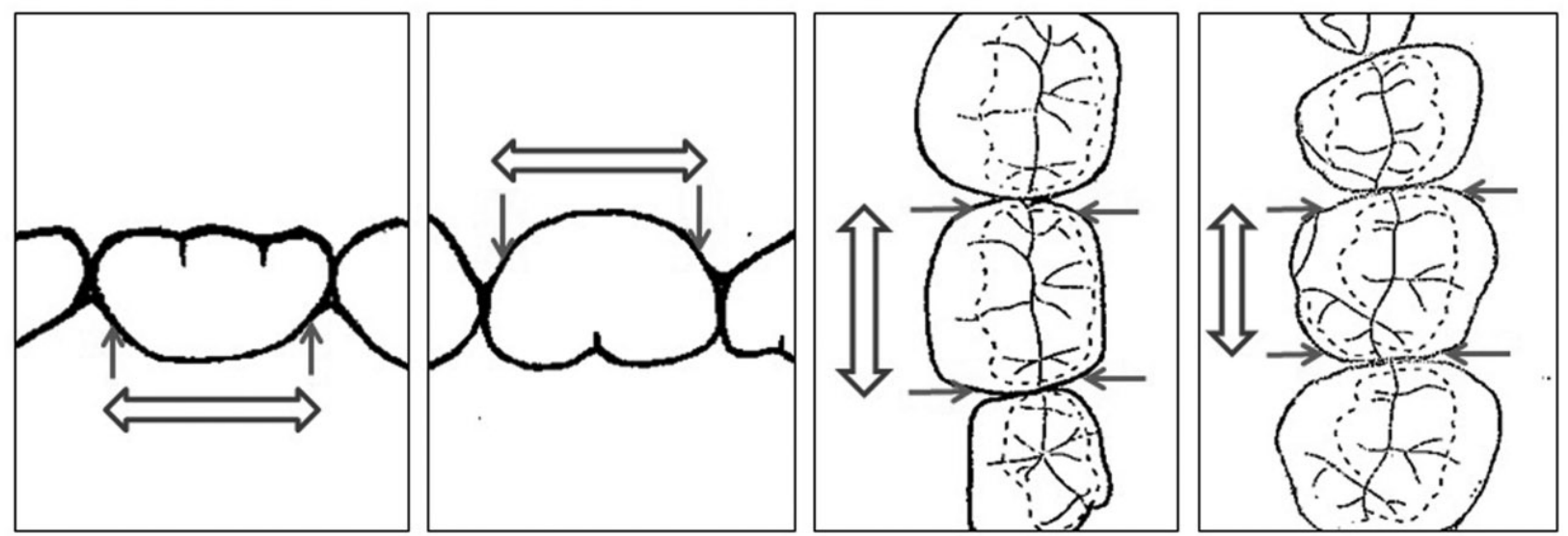

Fig. 1. Cervical mesiodistal width (C-MD). Measurements were made by measuring the distance between the two points halfway past the mesiobuccal (mesiolingual) line angle and the distobuccal (distolingual) line angle at the level of clinical cervical line. 
tal measuring points along the clinical cervical line (Fig. 1):

- Mesial point : halfway between the mesial line angle and the mesial contact point

- Distal point : halfway between the distal line angle and the distal contact point

C-MDs of primary second molars were measured using a digital caliper (Absolute, Mitutoyo, Kawasaki, Japan). One person made all measurements to the nearest hundredth of a millimeter. 20 dental casts were randomly selected and measured twice at a 2-week interval in order to assess intra-examiner reliability. Then the $\mathrm{C}-\mathrm{MDs}$ were compared with mesiodistal widths of rubber dam clamps \#203/204 (Dentech, Japan), \#10/11 (Dentech, Japan), and \#205 (Dentech, Japan) (Fig. 2). The widths of rubber dam clamps were measured by measuring the mesiodistal distance between prongs of rubber dam clamps at buccal and lingual sides respectively.

Statistical analysis was performed using SPSS 20 software (SPSS Inc, Chicago, Ill). Independent sample ttest and single sample t-test were used significant at the $p<0.05$ level, and intraclass correlation coefficient (ICC) was used to determine intra-examiner reliability.

\section{Results}

\section{Intra-examiner reliability}

Intraclass correlation coefficient (ICC) ranged from 0.88 to 0.98 , demonstrating almost to perfect reliability according to ICC interpretation scale by Landis and Koch $^{11)}$.

\section{C-MDs of primary second molars}

The C-MDs of primary second molars measured in this study are shown in Table 1. C-MDs of primary mandibular second molars were generally larger than those of primary maxillary second molars, and C-MDs measured at buccal sides were larger than those measured at lingual sides. There were no statistically significant differences between $\mathrm{C}-\mathrm{MDs}$ of male and female $(p>0.05)$. Bilateral asymmetry was found to be statistically significant ( $p=$ 0.04 ) at only one site $(55 / 65 B)$, of which the difference was only $0.13 \mathrm{~mm}$, showing relatively small clinical significance (Table 2). Other sites showed no significant difference between right and left $(p>0.05)$.
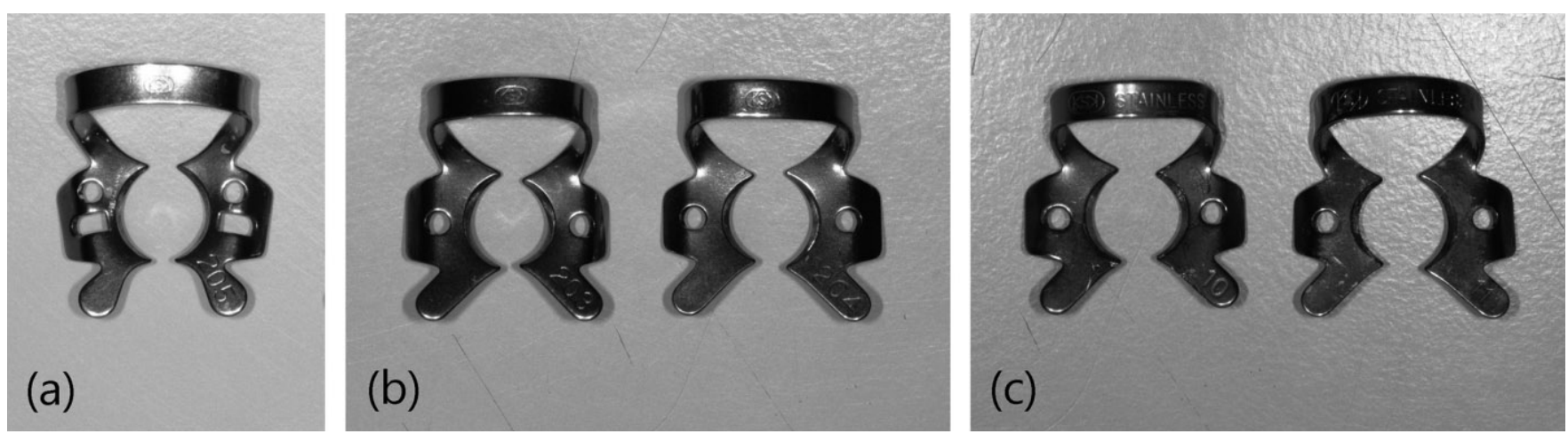

Fig. 2. Clamps for posterior teeth. (a) \#205 (b) \#203/204 (c)\#10/11.

Table 1. C-MDs of primary second molars ( $\mathrm{mm}$ )

\begin{tabular}{|c|c|c|c|c|c|c|c|}
\hline & \multicolumn{2}{|c|}{ Male } & \multicolumn{2}{|c|}{ Female } & \multirow{2}{*}{$p$-value } & \multicolumn{2}{|c|}{ Total } \\
\hline & $\mathrm{N}$ & mean $\pm S D$ & $\mathrm{~N}$ & mean+SD & & $\mathrm{N}$ & mean $\pm \mathrm{SD}$ \\
\hline $55 \mathrm{~B}$ & 49 & $8.20 \pm 0.43$ & 42 & $8.27 \pm 0.45$ & 0.46 & 91 & $8.23 \pm 0.44$ \\
\hline $55 \mathrm{~L}$ & 49 & $7.42 \pm 0.51$ & 42 & $7.49 \pm 0.44$ & 0.49 & 91 & $7.45 \pm 0.48$ \\
\hline $65 \mathrm{~B}$ & 54 & $8.07 \pm 0.42$ & 38 & $8.14 \pm 0.37$ & 0.39 & 93 & $8.10 \pm 0.40$ \\
\hline $65 \mathrm{~L}$ & 54 & $7.41 \pm 0.53$ & 38 & $7.42 \pm 0.41$ & 0.91 & 93 & $7.41 \pm 0.48$ \\
\hline $75 \mathrm{~B}$ & 55 & $9.25 \pm 0.46$ & 41 & $9.38 \pm 0.50$ & 0.18 & 96 & $9.31 \pm 0.48$ \\
\hline $75 \mathrm{~L}$ & 55 & $8.46 \pm 0.56$ & 41 & $8.54 \pm 0.45$ & 0.45 & 96 & $8.50 \pm 0.52$ \\
\hline $85 \mathrm{~B}$ & 53 & $9.27 \pm 0.55$ & 44 & $9.26 \pm 0.50$ & 0.47 & 97 & $9.28 \pm 0.52$ \\
\hline $85 \mathrm{~L}$ & 53 & $8.53 \pm 0.55$ & 44 & $8.50 \pm 0.48$ & 0.54 & 97 & $8.52 \pm 0.52$ \\
\hline
\end{tabular}

Independent sample t-test, significant at $p<0.05$ level

B: buccal, L: lingual 
Table 2. Bilateral difference of measurements

\begin{tabular}{lcc}
\hline & Lt-Rt differencea $(\mathrm{mm})$ & $p$-value \\
\hline $55 / 65 \mathrm{~B}$ & 0.13 & $0.04^{*}$ \\
$55 / 65 \mathrm{~L}$ & 0.04 & 0.60 \\
$75 / 85 \mathrm{~B}$ & -0.03 & 0.57 \\
$75 / 85 \mathrm{~L}$ & 0.02 & 0.83
\end{tabular}

Independent sample t-test, significant at $p<0.05$ level $(*)$

aright minus left

\section{Comparison with available clamps}

Averaged C-MDs for each site were used for comparison with rubber dam clamps (Table 3). C-MDs at all sites showed statistically significant difference to their corresponding widths in all rubber dam clamps examined. However, the amount of difference varied. When compared to \#203/204 and \#10/11, which are clamps commonly used for primary second molars, the discrepancy (mean C-MD minus clamp width) ranged from $0.24 \mathrm{~mm}$ to $-0.34 \mathrm{~mm}$ at buccal sides and $-0.07 \mathrm{~mm}$ to $0.17 \mathrm{~mm}$ at lingual sides in primary maxillary second molars, while larger discrepancy of $0.79 \mathrm{~mm}$ to $0.89 \mathrm{~mm}$ and $0.91 \mathrm{~mm}$ to $1.01 \mathrm{~mm}$ at buccal and lingual sides respectively were shown in primary mandibular second molars. That is, C-MDs of maxillary teeth were similar or slightly smaller than the widths of these rubber dam clamps, while C-MDs of mandibular teeth were larger than the widths of these rubber dam clamps and with a larger amount of discrepancy. On the other hand, the $\mathrm{C}$ MDs of mandibular teeth showed less discrepancy to the permanent molar clamp \#205.

\section{Discussion}

The benefits of rubber dam use are emphasized in pediatric dentistry. Proper fit of rubber dam clamp is an integral part in minimizing complications related to rub- ber dam application. Gaining secure contact between the jaw of the clamp and the tooth is important in rubber dam clamp retention. When not enough retention is gained supragingivally, the rubber dam clamps tend to be forced even more toward the gingiva, causing discomfort or pain, damage to gingival attachment, and nicks of the cementum on the root surfaces ${ }^{122}$. If the jaws of the clamp extend beyond the appropriate width, they may interfere with matrix and wedge placement, gingival impingement and trauma is more likely to occur, and complete seal around the anchor tooth is more difficult to achieve $^{13)}$. In pediatric patients, these can all lead to poor cooperation of the child or act as harmful stimuli that provoke the child during sedation. Therefore selection of an appropriate clamp is crucial. This study presents preliminary data of mesiodistal widths measured specifically at the level of the clinical cervical line, therefore providing reference for selection or manufacture of appropriate rubber dam clamps.

While there have been many studies regarding mesiodistal tooth crown dimensions worldwide ${ }^{7)}$, most of them used the measurement method by Moorees et al. ${ }^{10)}$, described by measuring the greatest distance between contact points using a sliding caliper held parallel to the occlusal surfaces. No studies exist on mesiodistal width measured at the cervical level of the tooth, especially at the clinical cervical line, where rubber dam clamps adapt on. In our study, we used the definition the cervical mesiodistal width (C-MD) to refer to the mesiodistal width of a tooth measured at the clinical cervical line, between two points where the prongs of the rubber dam clamp jaws would be placed. Since the jaws should be placed past the proximal line angle for stable grasp ${ }^{13)}$ but short to the contact point in order not to impinge the papillary tissue, the prongs should be placed between the proximal line angle and the contact point. Under this assumption, the mesial and distal measuring points

Table 3. Difference between mean C-MD and commercial clamp size

\begin{tabular}{|c|c|c|c|c|c|c|c|}
\hline & \multirow{2}{*}{$\begin{array}{l}\text { mean } \\
\text { C-MD } \\
(\mathrm{mm})\end{array}$} & \multicolumn{2}{|c|}{$\begin{array}{c}\# 203 / 204 \\
(B: 8.5 \mathrm{~mm}, \mathrm{~L}: 7.5 \mathrm{~mm})\end{array}$} & \multicolumn{2}{|c|}{$\begin{array}{c}\# 10 / 11 \\
(\mathrm{~B}: 8.4 \mathrm{~mm}, \mathrm{~L}: 7.6 \mathrm{~mm})\end{array}$} & \multicolumn{2}{|c|}{$\begin{array}{c}\# 205 \\
(\mathrm{~B}: 9.0 \mathrm{~mm}, \mathrm{~L}: 9.0 \mathrm{~mm})\end{array}$} \\
\hline & & differencea & $p$-value & differencea & $p$-value & differencea & $p$-value \\
\hline 55/65B & $8.16 \pm 0.42$ & -0.24 & $<0.001^{*}$ & -0.34 & $<0.001^{*}$ & -0.84 & $<0.001 *$ \\
\hline $55 / 65 \mathrm{~L}$ & $7.43 \pm 0.48$ & -0.17 & $<0.001 *$ & -0.07 & $0.04 *$ & -1.57 & $<0.001 *$ \\
\hline 75/85B & $9.29 \pm 0.50$ & 0.89 & $<0.001^{*}$ & 0.79 & $<0.001^{*}$ & 0.29 & $<0.001^{*}$ \\
\hline $75 / 85 \mathrm{~L}$ & $8.51 \pm 0.52$ & 0.91 & $<0.001 *$ & 1.01 & $<0.001^{*}$ & -0.49 & $<0.001^{*}$ \\
\hline
\end{tabular}

Single sample t-test, significant at $p<0.05$ level $(*)$

a mean C-MD minus clamp width of corresponding side 
of $\mathrm{C}-\mathrm{MD}$ were each defined as the point halfway between the mesial line angle and the mesial contact point, and the point halfway between the distal line angle and the distal contact point respectively.

The measurement results showed that C-MDs of primary second molars were approximately $1 \mathrm{~mm}$ larger in mandibular teeth than in maxillary teeth, and C-MDs measured at buccal sides were larger than those measured at lingual sides. No significant difference was found between C-MDs of male and female $(p>0.05)$. This was inconsistent with general findings of other studies that teeth are larger in males than in females ${ }^{8.9 .14}$. Although it is difficult to generalize our findings due to our small sample size, this inconsistency could be explained by some studies. According to Choi et al. ${ }^{9)}$, gender difference in crown diameter is more prominent in bucco-lingual dimension, and in a study of primary molar tooth size in Spanish children by Barberia et al. ${ }^{15)}$, least variability was shown in height and mesiodistal size, and primary second molars had less variability than primary first molars. Bilateral asymmetry of the present sample was found to be statistically significant at only one site- buccal side of maxillary teeth ( $p=$ 0.04). Nevertheless, clinical significance of this asymmetry was small $(0.13 \mathrm{~mm})$, and all other sites showed no significant difference between right and left $(p>0.05)$. Ballard $^{16)}$, Moorrees and Reed ${ }^{17)}$, Lee et al. ${ }^{18)}$, and Choi et al. ${ }^{9)}$ proposed that bilateral asymmetry does not exist in tooth size, and Barett et al ${ }^{19)}$, mentioned that difference between size of right and left teeth within an arch is negligible and therefore average size can be used as representative data. In compliance to this regard, averaged C-MD was used for further analysis with clamps.

C-MDs of primary second molars gained in this study were compared with widths of clamps \#203/204, \#10/11, and $\# 205$. Clamps $\# 203 / 204$ and $\# 10 / 11$ are common clamps for primary second molars. When compared to these clamps, the amount of discrepancy between the $\mathrm{C}^{-}$ MDs and widths of clamps were relatively small in maxillary teeth, while up to $1 \mathrm{~mm}$ of difference was shown in mandibular teeth. This implies that more clinically significant discrepancy, thus poor fit, exists between primary mandibular second molars and their clamps. On the other hand, when $\# 205$, a permanent molar clamp, was compared for reference, less discrepancy was shown to primary mandibular second molars. This suggests that in case the primary mandibular second molar is too large for \#203/204 or \#10/11 to adapt on, \#205 could be used as an alternative. Nevertheless, it should be noted that buccal and lingual widths solely are not the only factors determining the fit of the clamp. The relative position and angles between the four points of the prongs could also be an important factor, which was not studied in this study. Therefore, the discrepancy in widths shown in this study is enough to suggest that we are in need of a better clamp for primary mandibular second molars, but further study is needed to determine the fit between the clamps and primary maxillary second molars.

This study was confined to part of the Korean population. Difference in tooth size is known to exist between populations of different race and environment ${ }^{7,17,19,20)}$. According to Yeun et al. ${ }^{8}$, mesiodistal diameters of primary second molars are significantly larger in Japanese than in Chinese, and in a worldwide survey by Harris et al. ${ }^{7)}$, mesiodistal diameters of primary teeth are reported to be largest in native Australian aboriginals and smallest in Europeans. This implies that C-MDs would vary among different populations, and there could be no universal clamp that fits perfectly to teeth of all populations. However, the fact that there are no previous studies on cervical mesiodistal widths with the same objective as ours imposes a limitation on our study in that there are no comparable data or studies. For thorough investigation, data of other race should also be studied.

Another limitation of this study was reproducibility and accuracy of measurements. Reproducibility refers to the degree of agreement between measurements under unchanged conditions in repeated trials or by different people, and accuracy refers to the degree of closeness of measurements of a quantity to that quantity's actual value $^{21}$. Intra-examiner reliability assessed in this study showed almost-to-perfect reliability (ICC value $0.88^{-}$ 0.98). However, the accuracy of our measurements remains questionable, since the proximal line angle of a tooth, used as a reference point in defining our measurement point, was a rather indefinite point to detect accurately. This could be overcome by measuring the greatest distance between contact points, a rather definite reference point, and then subtracting a certain predefined length from the measurement instead of having to use the indefinite line angles for reference for measurement. However, in this case, defining the amount of length to be subtracted brings up another issue. Another method we could think of was to draw a bisector of two tangent lines at each corner to achieve more reproducible measuring points, but this method was rejected because 
there is no support that this method relates to appropriate position for clamp adaptation.

The C-MDs of primary second molars were measured in this study specifically under the intention of providing preliminary data for selection or manufacture of precise rubber dam clamps. Although we defined the C-MD under the assumption that the prongs of the clamps should be placed between the proximal line angle and the contact point of a tooth, thorough investigation is needed to confirm the most appropriate position for the clamp to be placed on a tooth. In order for this to be possible, not only mesiodistal widths but also other three-dimensional morphological characteristics of a tooth such as convexity and undercut areas should be taken into consideration. Three dimensional scanners could be used for more precise measurements than vernier calipers and at the same time be used for analyzing additional three dimensional morphological data.

\section{Conclusions}

We investigated cervical mesiodistal widths of primary second molars in Korean children and compared them with commercial rubber dam clamps commonly used in pediatric dentistry. Based on this study's results, CMDs of primary mandibular second molars were generally larger than those of primary maxillary second molars, and C-MDs of buccal sides were larger than those of lingual sides. No significant difference was observed between $\mathrm{C}-\mathrm{MDs}$ of male and female primary second molars $(p>0.05)$. All mean $\mathrm{C}-\mathrm{MDs}$ measured in this study were statistically significantly different to corresponding widths of rubber dam clamps $(p<0.05)$. However, our comparison showed that $\# 10 / 11$ and $\# 203 / 204$ clamps fit relatively well to primary maxillary second molars, while larger discrepancy is shown in mandibular ones, suggesting our need for a better clamp with proper size for primary mandibular second molars.

\section{References}

1. Murray MJ: Value of the rubber dam in operative dentistry. J Am Acad Gold Foil Operators, 3:25-31, 1960.

2. Raskin A, Setcos JC, Vreven J, et al.: Influence of the isolation method on the 10-year clinical behaviour of posterior resin composite restorations. Clin Oral Investig, 4:148-152, 2000.
3. Slawinski D, Wilson S: Rubber Dam Use: A Survey of Pediatric Dentistry Training Programs and Private Practitioners. Pediatr Dent, 32:64-68, 2010.

4. Yi SH, Kim JB, Jang KT, Kim CC: A case study of various clinical application of the rubber dam in pediatric dentistry. $J$ Korean Acad Pediatr Dent, 24:549-555, 1997.

5. Schorer-Jensma MA, Veerkamp JS: A comparison of paediatric dentists' and general dental practitioners' care patterns in paediatric dental care. Eur Arch Paediatr Dent, 11:93-96, 2010.

6. Yoon RK, Chussid S: Topical anesthesia for rubber dam clamp placement in sealant placement: comparison of lidocaine/prilocaine gel and benzocaine. Pediatr Dent, 31:377-381, 2009.

7. Harris EF, Lease LR: Mesiodistal tooth crown dimensions of the primary dentition: a worldwide survey. Am J Phys Anthropol, 128:593-607, 2005.

8. Yuen KK, So LL, Tang EL: Mesiodistal crown diameters of the primary and permanent teeth in southern Chinese--a longitudinal study. Eur J Orthod, 19:721-731, 1997.

9. Choi JE, Cheong TS, Kim S: A Morphometric study on the primary molars and preformed stainless steel crown. J Korean Acad Pediatr Dent, 28:355-361, 2001.

10. Moorrees CFA, Thomsen SO, Jensen E, et al.: Mesiodistal crown diameters of the deciduous and permanent teeth in individuals. $J$ Dent Res, 36:3947, 1957.

11. Landis JR, Koch GG: The measurement of observer agreement for categorical data. Biometrics, 33:159174, 1977.

12. Wakabayashi $\mathrm{H}$, Ochi $\mathrm{K}$, Tachibana $\mathrm{H}$, et al.: A clinical technique for the retention of a rubber dam clamp. J Endod, 12:422-424, 1986.

13. Roberson TM, Heymann HO, Swift EJ: Sturdevant's Art and Science of Operative Dentistry. 5th edn. Mosby, St. Louis, 463-487, 2006.

14. Lysell L, Myrberg N: Mesiodistal tooth size in the deciduous and permanent dentitions. Eur J Orthod, 4:113-122, 1982.

15. Barberia E, Suarez MC, Villalon G, et al.: Standards for mesiodistal and buccolingual crown size and height of primary molars in a sample of Spanish children. Eur J Paediatr Dent, 10:169-175, 2009.

16. Ballard ML: Asymmetry in tooth size : A factor in 
the etiology, diagnosis and treatment of malocclusion. Angle Orthod, 14:65-70, 1944.

17. Moorrees CFA, Reed RB: Correlation among crown diameters of human teeth. Arch Oral Biol, 9:685697, 1964.

18. Lee JB, Kim CC, Hahn SH, et al.: A morphometric study of the maxillary primary first molars using three-dimensional scanner. $J$ Korean Acad Pediatr Dent, 33:643-652, 2006.

19. Barrett MJ, Brown T, McDonald MR: Dental obser- vations on Australian aborigions: Mesiodistal crown diameters of permanent teeth. Aust Dent J, 8:150155, 1963.

20. Garn SM, Lewis AB, Kerewsky RS: Genetic, nutritional, and maturational correlate of dental development. J Dent Res, 44:228-242, 1965.

21. Sim EJ, Hwang HS, Moon JD: A study on the error of tooth size measurements. Korea J Orthod, 29:491-501, 1999. 
국문초록

\title{
한국인 소아에서 제2유구치에 대한 러버댐 클램프의 적합도에 관한 연구
}

\author{
박미래 ${ }^{1}$ - 마연주 ${ }^{1}$ · 안병덕 ${ }^{2}$ \\ ${ }^{1}$ 이화여자대학교 목동병원 소아치과, \\ ${ }^{2}$ 이화여자대학교 의학전문대학원 치과학교실 소아치과학전공
}

질 높은 치료를 제공하고 안전한 치료환경을 만들기 위한 러버댐 사용의 중요성은 소아치과에서 더욱 강조된다. 한편 잘못 된 클램프의 장착으로 발생하는 통증과 불완전한 방습은 협조도를 떨어뜨리고 진정 치료 중 방해가 되기도 한다.

본 연구에서는 혼합치열기 아동 110 명의 경석고 모형을 통해 제 2 유구치의 치경부 근원심 폭경을 측정하고 이를 \#203/204, \#10/11, \#205 클램프(Dentech, Japan)의 근원심 폭경과 비교하여 다음과 같은 결과를 얻었다.

제 2 유구치의 치경부 근원심 폭경은 하악이 상악보다 크고, 협측이 설측 보다 컸다. 모든 위치의 계측값이 클램프 폭경과 비교 시 통계적으로 유의한 차이가 있었으나, 그 차이값이 상악 제 2 유구치에서는 작은 반면 하악 제 2 유구치에서는 $1 \mathrm{~mm}$ 에 가까운 것으로 나타났다. 상악 제 2 유구치는 \#203/204 및 \#10/11 클램프와 비교적 잘 맞는 반면 하악 제 2 유구치를 위해서 는 보다 적절한 크기의 클램프가 필요할 것으로 보인다.

주요어: 러버댐 클램프, 치경부 폭경, 유치 